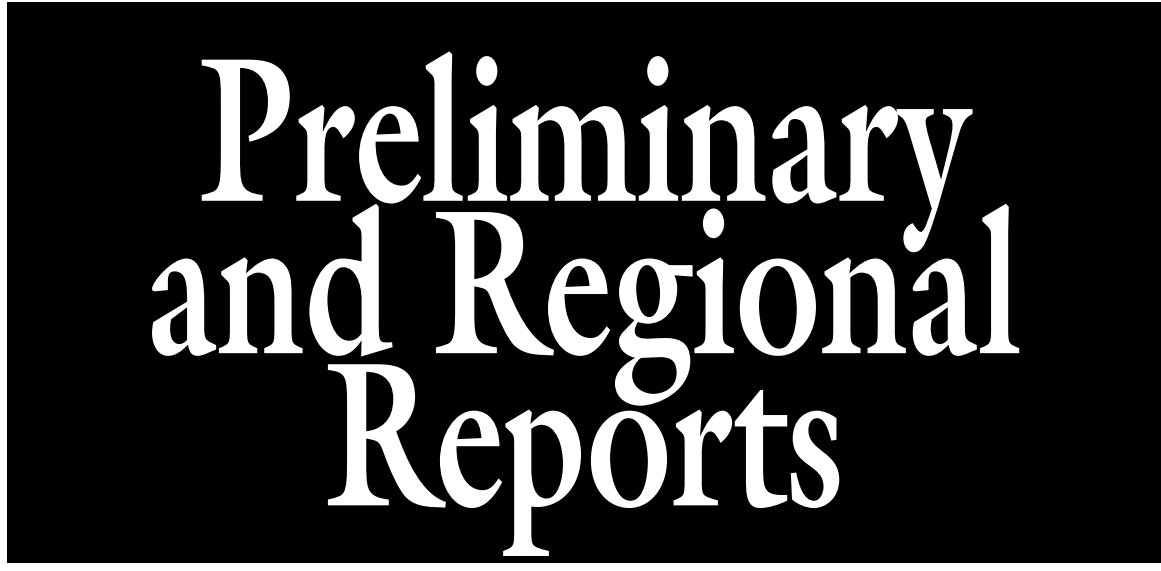

\section{The Use of Irrigation for Frost Protection for Blueberry in the Southeastern United States}

\author{
Elizabeth Conlan $^{1,5}$, Tatiana Borisova ${ }^{2}$, Erick Smith ${ }^{3}$, \\ Jeffrey Williamson ${ }^{1}$, and Mercy Olmstead ${ }^{1,4}$
}

\begin{abstract}
Additional Index words. Florida, Georgia, Vaccinium, low-chill, bud stage, grower survey, freeze damage, extension

Summary. Freeze events between January and April can result in major crop and economic losses for growers of low-chill, early-ripening varieties of blueberry (Vaccinium sp.) in Florida and Georgia. The objective of this research was to determine current responses by blueberry growers to freeze events. Blueberry growers in Florida and Georgia were surveyed about frost protection decision criteria. Growers had differing opinions on when to make the decision to frostprotect blueberry crops. Almost all $(98.9 \%)$ of the respondents $(n=94)$ who reported using at least one method of active frost protection reported using irrigation. Farm size, as measured by blueberry acreage, did not influence decisions regarding the use of active frost protection measures. Blueberry growers, on average, reported that a loss of up to $30 \%$ to $39 \%$ of their crop could be tolerated and still produce a marketable crop. However, they may have been overly cautious at the early bud stages, with $\approx \mathbf{4 0 \%}$ and $55 \%$ of respondents protecting at the bud swell and tight cluster stages, respectively. Understanding the use of irrigation as a frost protection practice in the southeastern United States can aid in improving frost protection recommendations, helping growers maximize yield and saving water and money.
\end{abstract}

$\mathrm{B}$ lueberry acreage in Florida and Georgia has more than doubled since 2000. In 2016, blueberries were harvested from

This research was supported by a Florida Department of Agriculture \& Consumer Services Specialty Crop Block Grant.

${ }^{1}$ Horticultural Sciences Department, University of Florida, 2135 Fifield Hall, Gainesville, FL 32611

${ }^{2}$ Food and Resource Economics Department, University of Florida, 1097 McCarty Hall, P.O. Box 110240, Gainesville, FL 32611

${ }^{3}$ Department of Horticulture, University of Georgia, Coastal Plain Experiment Station, 2360 Rainwater Road, Tifton, GA 31793

${ }^{4}$ Current address: California Strawberry Commission, Watsonville, CA 95076

${ }^{5}$ Corresponding author. E-mail: elizabethconlan@ gmail.com.

https://doi.org/10.21273/HORTTECH04008-18
4700 acres in Florida and 16,900 acres in Georgia. The two states accounted for $23.3 \%$ of the total U.S. blueberry harvested area (U.S. Department of Agriculture, 2017). Despite early-ripening varieties being susceptible to spring frost injury
(Strik and Yarborough, 2005), lowchill, early harvest southern highbush blueberries [SHB (Vaccinium corymbosum interspecific hybrids)] have been extensively planted in this region to take advantage of pricing for entrance into early U.S. market windows (Brazelton, 2015; England, 2015). SHB varieties begin to flower in January in both Florida and Georgia, with frost events occurring from January until April. Depending on the floral bud development stage and when temperatures drop to freezing or below, damage can be significant (Warmund et al., 2008). As a result, frost-protection measures commonly are used to mitigate crop loss in Florida and Georgia (England, 2015; NeSmith, 2008).

Cost of orchard establishment can be $\$ 10,000$ to $\$ 12,000$ per acre or more (Fonsah et al., 2013; Singerman et al., 2016). Most growers use lowvolume (usually drip) irrigation systems to address crop water requirements and overhead irrigation for frost protection. Frost protection, primarily overhead irrigation systems, can add another $\$ 2300$ per acre to establishment costs (Singerman et al., 2016). Once established, operating costs for frost protection through overhead irrigation can be low (as compared with wind machines and heaters) (Poling, 2008). With relatively low operating costs, the main barrier for the use of frost protection is its limited effectiveness. In general, when temperature drops to $-7^{\circ} \mathrm{C}$ or wind speed increases to $16 \mathrm{~km} \cdot \mathrm{h}^{-1}$ or above, frost protection may not be effective. Other matters that growers should consider in frost-protecting their crops include increased evaporative cooling due to wind, the potential for poor ice formation, ice accumulation breaking and stripping flowers from the plant, and water restrictions due to regulatory requirements or

\begin{tabular}{llll}
\hline $\begin{array}{l}\text { Units } \\
\text { To convert U.S. } \\
\text { to SI, multiply by }\end{array}$ & U.S. unit & SI unit & $\begin{array}{l}\text { To convert SI } \\
\text { to U.S., multiply by }\end{array}$ \\
\hline 0.4047 & $\mathrm{acre}(\mathrm{s})$ & $\mathrm{ha}$ & 2.4711 \\
0.3048 & $\mathrm{ft}$ & $\mathrm{m}$ & 3.2808 \\
0.0929 & $\mathrm{ft}^{2}$ & $\mathrm{~m}^{2}$ & 10.7639 \\
3.7854 & $\mathrm{gal}$ & $\mathrm{L}$ & 0.2642 \\
25.4 & $\mathrm{inch}(\mathrm{es})$ & $\mathrm{mm}$ & 0.0394 \\
3.6000 & $\mathrm{kWh}$ & $\mathrm{MJ}$ & 0.2778 \\
1.6093 & $\mathrm{mph}$ & $\mathrm{km} \cdot \mathrm{h}^{-1}$ & 0.6214 \\
6.8948 & $\mathrm{psi}$ & $\mathrm{kPa}$ & 0.1450 \\
$\left({ }^{\circ} \mathrm{F}-32\right) \div 1.8$ & ${ }^{\circ} \mathrm{F}$ & ${ }^{\circ} \mathrm{C}$ & $\left({ }^{\circ} \mathrm{C} \times 1.8\right)+32$
\end{tabular}


physical limitations of the irrigation system (Perry, 1998; Poling, 2008; Snyder and Melo-Abreu, 2005).

Given these constraints, growers initiate frost protection in advance of a frost or freeze event when the temperature is anticipated to reach critical levels where lethal damage to reproductive tissue can occur (critical bud temperature values). Figure 1 illustrates the established critical temperatures for different blueberry bud stages (Patten et al., 1991; Spiers, 1978). Another problematic constraint is the information gaps related to variety, climate, and bud stage in recommendations provided to growers in Florida and Georgia. As a result, growers in Florida and Georgia must rely on critical bud temperature information developed for other regions. frost protection at a particular time depends on the cost, information available, and risk attitude of growers to adjust their practices in response to frost forecasts (Crane et al., 2010; Hu et al., 2006; Klockow et al., 2010; Kusunose and Mahmood, 2016; Mase and Prokopy, 2014; Stewart et al., 1984). The study by Stewart
Overall, the decision to start

et al. (1984), which focused on frostprotection decisions of fruit growers in central Washington, found multiple on-farm weather resources and strategies available to growers to mitigate frost. Perceptions of the weather forecast quality and applicability of the forecast to growers' production systems were crucial for the decision to frost-protect fruit crops.

Research shows that more studies examining the determinants of frost-protection decisions are needed, given the potentially high economic impact of frost and the need for more efficient frost-protection systems and opportunities to save water and energy by developing precision frostprotection technologies (Chevalier et al., 2012; Simnitt et al., 2017). The objective of this project was to identify, by survey, the prevalence of frost-protection systems, the use of information resources to mitigate damage caused by frost events, and the decision timing for operating a frost-protection system by Florida and Georgia blueberry growers.

\section{Materials and methods}

A paper-based survey was developed that contained 19 questions

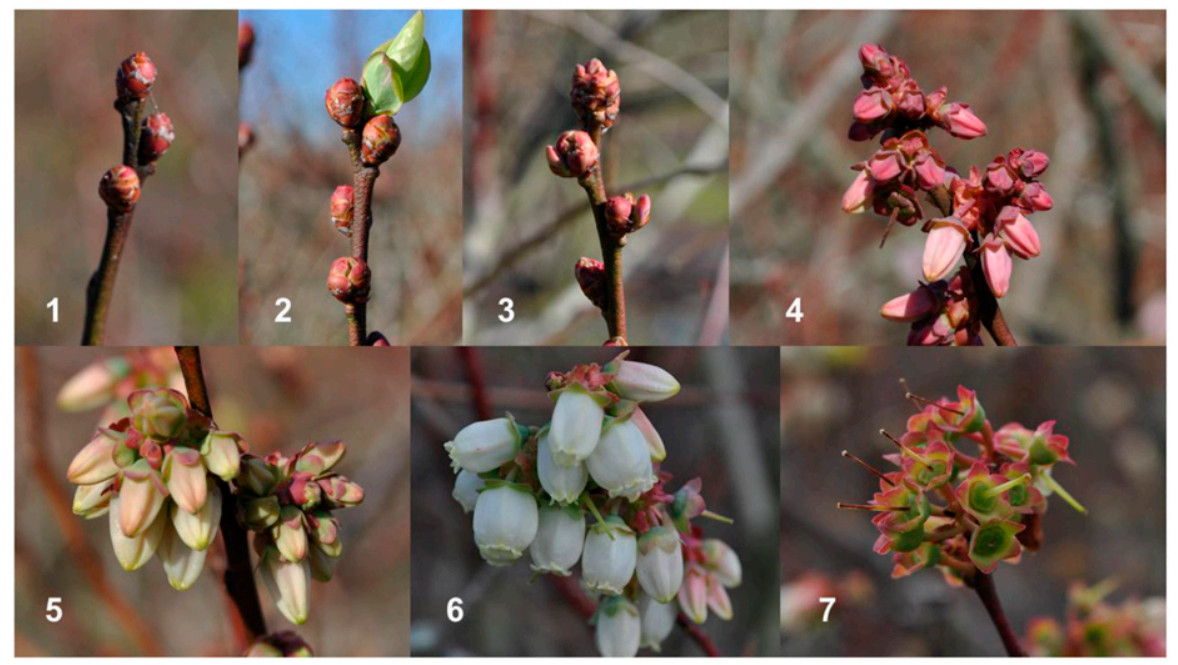

Fig. 1. Blueberry floral bud stages: Stage $1=$ dormant-no visible swelling, bud scales completely enclose florets; Stage 2 = bud swell-visible swelling of bud, scales separating, flowers still completely enclosed (critical temperature range from 10 to $15^{\circ} \mathrm{F}$ ); Stage 3 = tight cluster-bud scales separated, apices of flowers visible (critical temperature range from 20 to $23{ }^{\circ} \mathrm{F}$ ); Stage 4 = early pink-bud scales abscised, individual flowers, typically pinkish in color, distinguishable (critical temperature range from 23 to $25{ }^{\circ} \mathrm{F}$ ); Stage 5 = late pink-individual flowers separated, corollas unexpanded and closed (critical temperature range from 24 to $27^{\circ} \mathrm{F}$ ); Stage 6 = full bloom-corollas open (critical temperature of $28{ }^{\circ} \mathrm{F}$ ); and Stage 7 = petal fall-corollas dropped (critical temperature of $32{ }^{\circ} \mathrm{F}$ ) (Michigan State University, 2012; Spiers, 1978). Photos by Elizabeth Conlan; $\left({ }^{\circ} \mathrm{F}-32\right) \div$ $1.8={ }^{\circ} \mathrm{C}$. directed to identify freeze-protection practices and decision criteria. The target population for the survey was commercial blueberry growers of Florida and Georgia. Questions focused on decision management based on bud stage, meteorological information, and informational resources. Further, questions were asked to identify varieties under frost protection, equipment used to frost-protect crops, and areas of frost protection. Before distribution to growers, the survey instrument was pretested, and input from the pretests was incorporated into the final survey language and design. The Florida and Georgia blueberry surveys were submitted to the University of Florida and University of Georgia Institutional Review Boards, respectively, where they received exempt status.

The Florida blueberry survey was distributed and collected at the Fall Blueberry Short Course of the Florida Blueberry Grower's Association in Oct. 2015. In Georgia, surveys were administered and collected in collaboration with extension activities at county meetings in southern Georgia between Nov. 2015 and Jan. 2016.

Survey responses were coded and analyzed using SAS (version 9.4; SAS Institute, Cary, NC). Summary statistics, including mean and standard deviation, were calculated for each question, and questions were crosstabulated and tested for significance using the Pearson's $\chi^{2}$ test and the Kolmogorov-Smirnov test.

\section{Results and discussion}

Demographic overview. After we eliminated nonqualifying respondents, the final number in the survey was 106 . Of the 106 respondents, 94 used active frost protection, with 46 from Florida (48.9\%) and 48 from Georgia (51.1\%). Most respondents were from farms of less than 51 acres (Table 1). Taking the midpoint for each of the acreage response intervals, we estimate that these Florida and Georgia growers manage about 1696 and 2850 acres, respectively, or about $37.7 \%$ and $19 \%$ of the total blueberry acreage in their respective states.

Most growers had experience with blueberry production, with the average number of years growing 
blueberries being 10.1 years in Florida and 13.1 in Georgia. A significantly larger (Wilcoxon rank-sum test, $P=0.05$ ) proportion of Florida respondents $(\approx 40 \%)$ had grown blueberries for 6 years or less, compared with less than $10 \%$ of Georgia respondents, reflecting the relative youth of Florida's blueberry industry.

In both states, growers reported producing a mix of varieties, mostly $\mathrm{SHB}$. The median number of varieties selected by respondents from the questionnaire list was three; in addition, many respondents, including those growers with rabbiteye blueberry (Vaccinium ashei) varieties, selected the "other" option (Table 2). The SHB varieties
Farthing and Emerald were popular in both states; in addition, the majority of respondents in Florida reported growing Jewel, whereas the majority in Georgia reported growing Star.

Of the respondents who reported using at least one method of active frost protection, almost all $(98.9 \%)$ used irrigation for frost protection (Table 3). The emphasis was on using a frost-protection system that minimizes production losses with the least amount of damage to the plants. The water source for irrigation was statistically different between Florida and Georgia, with Florida growers using more groundwater and Georgia growers using more on-farm

Table 1. Farm acreage of blueberries reported by growers from Florida and Georgia in response to the question "how many acres on your farm are dedicated to blueberry production?"

\begin{tabular}{lccccccc}
\hline & & \multicolumn{6}{c}{ Proportion of responses (\%) } \\
\cline { 3 - 8 } State & Respondents (no.) & $\begin{array}{c}\text { Less than } \\
\mathbf{5} \text { acres }^{\mathbf{y}}\end{array}$ & $\begin{array}{r}\mathbf{5 - 1 0} \\
\text { acres }\end{array}$ & $\begin{array}{c}\mathbf{1 1 - 2 5} \\
\text { acres }\end{array}$ & $\begin{array}{c}\mathbf{2 6 - 5 0} \\
\text { acres }\end{array}$ & $\begin{array}{c}\mathbf{5 1 - 7 5} \\
\text { acres }\end{array}$ & $\begin{array}{c}\text { More than } \\
\mathbf{7 5} \text { acres }\end{array}$ \\
\hline Florida & 44 & 9.1 & 18.2 & 22.7 & 25.0 & 9.1 & 15.9 \\
Georgia & 48 & 6.3 & 8.3 & 25.0 & 16.7 & 14.6 & 29.2 \\
\hline
\end{tabular}

${ }^{\mathrm{z}}$ From a survey of freeze protection practices and decision criteria by blueberry growers in Florida and Georgia administered at extension meetings in 2015 and 2016.

${ }^{\mathrm{y}} 1$ acre $=0.4047$ ha

Table 2. Proportion of blueberry growers in Florida and Georgia who indicated growing specific southern highbush blueberry varieties in response to the survey question "which of the following varieties do you grow commercially? (Mark all that apply)" $(\mathrm{n}=93)$.

\begin{tabular}{lccc}
\hline & \multicolumn{3}{c}{ Proportion of respondents (\%) } \\
\cline { 2 - 4 } Variety & Florida & Georgia & Total sample \\
\hline Farthing & 56 & 71 & 63 \\
Emerald & $93^{*}$ & $65^{*}$ & 78 \\
Jewel & $71^{*}$ & $2^{*}$ & 35 \\
Meadowlark & 53 & 38 & 45 \\
Rebel & $7^{*}$ & $50^{*}$ & 29 \\
San Joaquin & 2 & 8 & 5 \\
Star & $16^{*}$ & $92^{*}$ & 55 \\
Other & $73^{*}$ & $29^{*}$ & 51
\end{tabular}

*The difference in proportion of growers producing the variety between states is significantly different at $P \leq 0.01$ using Pearson's $\chi^{2}$ test.

Table 3. For the blueberry growers in Florida and Georgia who use active frostprotection methods, the relative use of various methods. ${ }^{\mathrm{z}}$

\begin{tabular}{lccccc}
\hline & & \multicolumn{4}{c}{ Proportion of respondents (\%) } \\
\cline { 3 - 6 } State & Respondents (no.) & Irrigation & Wind machines & Cover & Heat \\
\hline Florida & 46 & 97.8 & 2.2 & 4.4 & 0.0 \\
Georgia & 48 & 100.0 & 10.4 & 0.0 & 0.0 \\
Total sample & 94 & 98.9 & 6.4 & 2.1 & 0.0 \\
\hline
\end{tabular}

${ }^{\mathrm{z}}$ The responses are from a survey of freeze-protection practices and decision criteria by blueberry growers in Florida and Georgia administered at extension meetings in 2015 and 2016 and in response to the question "what frost protection strategies for blueberries do you use? (Mark all that apply)." Since some growers use multiple frostprotection measures, the sum of proportions for various irrigation methods exceed $100 \%$. No statistical differences were found between states using Pearson's $\chi^{2}$ at $P=0.1$. ponds. (Table 4). Factors contributing to the predominance of well water as a source for freeze protection in Florida are the ease of access (with shallow aquifers available in most blueberry-producing Florida regions) and the waterpermitting procedures (with permits usually making allowances for freeze protection that are not counted against the water permitted for supplemental irrigation). In Georgia, most growers who freeze-protect blueberry crops draw water from artificial ponds to reduce well water drawdown.

Sprinkler type also varied by state: wobbler sprinklers in Florida vs. impact sprinklers in Georgia (Table 4). The main difference in the choice of sprinkler type may be that Georgia tends to have longer, more-frequent freezes. Impact sprinklers have changeable nozzles to deliver greater volumes of water, which may be needed in more severe freezes, or to turn the pressure up at the pump to deliver more water without damaging the sprinklers.

INFORMATION CONSIDERED IN FROST-PROTECTION DECISIONS. Growers were asked to evaluate the importance of climatic and crop factors on the decision to initiate irrigation for frost protection (Table 5 ). Five factors (air temperature, dew point, wind speed, bud stage, and freeze duration) identified in the literature (Perry, 1998; Poling, 2008; Stewart et al., 1984) as important were presented to the growers. Results show that growers placed air temperature, dew point, wind speed, and bud stage as very important indicators, at $77.9 \%, 74.2 \%, 77.3 \%$, and $85.1 \%$, respectively, to activate frost protection. By stage 5 (late pink stage) (Fig. 1), less than $10 \%$ of the respondents would not frost protect and the majority would begin using the system when the temperature reached $31^{\circ} \mathrm{F}$. Although an irrigation system, once started, should be run until the temperature rises above freezing and the ice is melting or risk crop damage (Snyder and MeloAbreu, 2005), only $56.8 \%$ of the respondents thought the duration of a freeze event was very important.

Location was the only farm characteristic that significantly affected the ranking of importance of the factors related to irrigation initiation. 
Specifically, wind speed was rated less important by Florida growers [62.8\% of Florida respondents rated it as "very important," compared with $91.1 \%$ of respondents in Georgia $\left(\chi^{2}\right.$ test, $P=0.01)$ ] since windy, advective freeze events could be a greater challenge for growers in Georgia. The analysis of the other farm characteristics (years in blueberry production and size of operation) did not reveal any statistically significant relations (Pearson's $\chi^{2}$ test, $P=0.05$ ).

Respondents revealed that they regularly access weather information, with $81 \%$ gathering information from on-farm meteorological devices. In addition, growers access universitysupported systems frequently (Table 6).
In Florida and Georgia, the Florida Automated Weather Network (FAWN) and Georgia Automated Environmental Monitoring Network (GAEMN), respectively, were used occasionally or regularly by $\approx 90 \%$ of respondents. FAWN and GAEMN were created to provide weather data from areas throughout Florida and Georgia underserved by the National Weather Service (Chevalier et al., 2012). This suggests growers are interested in comparing their meteorological monitoring devices with an off-farm source, which may add confidence to their decision process. This conclusion is similar to results found by Crane et al. (2010) that most farmers in Georgia used three sources of weather information to cross-check data from various sources. It should be noted that the survey only asked growers how often they received weather information from these sources and not what sources they use when determining the risk of a future freeze event.

Crane et al. (2010) reported that social networks are important for interpreting the weather information, which includes other growers, extension agents, and business interactions with suppliers and buyers. Our findings are consistent with these results, with the top-ranked resource consulted when deciding to turn on irrigation for frost protection being other growers $(62 \%)$ (Table 7$)$, who may be considered one of the most

Table 4. Irrigation water source and sprinkler type as reported by blueberry growers in Florida and Georgia in response to the questions "what is the primary source of water for irrigation on your farm?" and "what type of sprinkler do you use for blueberry frost protection? (Mark all that apply).”

\begin{tabular}{|c|c|c|c|c|c|c|c|c|c|}
\hline \multirow[b]{3}{*}{ State } & \multicolumn{5}{|c|}{ Water source } & \multicolumn{4}{|c|}{ Sprinkler type } \\
\hline & \multirow[b]{2}{*}{ Respondents (no.) } & \multicolumn{4}{|c|}{ Proportion of respondents (\%) } & \multirow[b]{2}{*}{ Respondents (no.) } & \multicolumn{3}{|c|}{ Proportion of respondents (\%) } \\
\hline & & $\begin{array}{c}\text { Ground } \\
\text { water }\end{array}$ & $\begin{array}{c}\text { Surface } \\
\text { water }\end{array}$ & $\begin{array}{c}\text { On-farm } \\
\text { pond }\end{array}$ & Other & & Overhead & Wobbler & Other \\
\hline Florida & 43 & 88.4 & 4.7 & 4.7 & 2.3 & 45 & $40.0^{*}$ & $75.6^{*}$ & 11.1 \\
\hline Georgia & 44 & 34.1 & 4.6 & 52.3 & 9.1 & 47 & $89.4^{*}$ & $4.3^{*}$ & 6.4 \\
\hline Total sample & 87 & 60.9 & 4.6 & 28.7 & 5.8 & 92 & 65.2 & 39.1 & 8.7 \\
\hline
\end{tabular}

${ }^{\mathrm{z}}$ The hypothesis that the water source use is the same in the two states was rejected at $P=0.001$ using Pearson's $\chi^{2}$ test.

*Significantly different between rows and $P \leq 0.001$ using Pearson's $\chi^{2}$ test.

Table 5. Importance of five factors in the decision to activate an irrigation system for frost protection according to Florida and Georgia blueberry growers responding to the question, "how important are the following factors in deciding whether to turn on your irrigation system?"

\begin{tabular}{lcccccc}
\hline & & \multicolumn{4}{c}{ Proportion of responses (\%) } \\
\cline { 3 - 6 } Factor & Responses (no.) & Not important & $\begin{array}{c}\text { Of little } \\
\text { importance }\end{array}$ & $\begin{array}{c}\text { Moderately } \\
\text { important }\end{array}$ & Important & Very important \\
\hline Air temperature & 86 & 0 & 0 & 0 & 22.1 & 77.9 \\
Dew point & 89 & 1.1 & 3.4 & 4.5 & 16.9 & 74.2 \\
Wind speed & 88 & 0 & 1.1 & 2.3 & 19.3 & 77.3 \\
Bud stage & 87 & 0 & 0 & 1.2 & 13.8 & 85.1 \\
Expected duration of & 81 & 3.7 & 6.2 & 9.9 & 23.5 & 56.8 \\
$\quad$ freeze/frost event & & & & & &
\end{tabular}

${ }^{\mathrm{z}}$ From a survey of frost-protection practices and decision criteria administered at extension meetings in 2015 and 2016.

Table 6. For the Florida and Georgia blueberry growers who use active frost protection: Frequency of weather information obtained by survey from four weather sources [the Florida Automated Weather Network (FAWN) was listed on Florida surveys and Georgia Automated Environmental Monitoring Network (GAEMN) was listed on Georgia surveys]. ${ }^{\mathrm{z}}$

\begin{tabular}{|c|c|c|c|c|c|}
\hline Weather sources & Respondents (no.) & \multicolumn{4}{|c|}{ Proportion of respondents (\%) } \\
\hline On-farm weather system/thermometers & 79 & 5.1 & 3.8 & 10.1 & 81.0 \\
\hline NOAA & 74 & 21.7 & 6.8 & 28.4 & 43.2 \\
\hline The Weather Channel (The Weather Co., Atlanta, GA) & 82 & 20.7 & 2.4 & 26.8 & 50.0 \\
\hline Other & 48 & 10.4 & 8.3 & 25.0 & 56.3 \\
\hline
\end{tabular}

${ }^{\mathrm{z}}$ Frequency data are from a survey of blueberry growers in Florida and Georgia in response to the question "how often do you get your weather information from the following sources?”

NOAA $=$ National Oceanic and Atmospheric Administration. 
trusted sources of information by growers (Mase and Prokopy, 2014). This finding supports the "train the trainer" approach to extension programs (Warner et al., 2014), where extension agents rely on communicating with the opinion leaders who then communicate with the rest of the farming community, is reasonable.

State extension services also were consulted about irrigation initiation by

Table 7. Percentage of Florida and Georgia blueberry growers who use information from other growers, extension services, and industry activate an irrigation system for frost protection $(\mathrm{n}=86)$. $^{\mathrm{z}}$

\begin{tabular}{lc}
\hline Information source & Consulting (\%) \\
\hline Advice from & 67.4 \\
$\quad$ other growers & \\
Extension, including: & $39.5^{\mathrm{y}}$ \\
Agents & 22.1 \\
Extension websites & 23.3 \\
Industry publications & 27.9 \\
\hline
\end{tabular}

${ }^{\mathrm{z}}$ Response data are from a survey of frost-protection practices and decision criteria by blueberry growers in Florida and Georgia to the question, "what resources do you consult when deciding to turn on your irrigation system for freeze protection? (Mark all that apply)."

${ }^{y}$ Combined responses related to agents, websites, and other extension products. publications when deciding to

more than $20 \%$ of growers. Although the use of extension service in general was similar in the two states, extension website resources specifically were significantly more popular in Georgia than in Florida [ $34 \%$ and $10.2 \%$ of respondents, respectively $\left(\chi^{2}\right.$ test, $\left.\left.P=0.01\right)\right]$. It is routine for Georgia extension agents to distribute University of Georgia extension publications to clients. In contrast, $51.3 \%$ of respondents in Florida, compared with $26.1 \%$ in Georgia, relied on other resources.

SWITCHING FROST PROTECTION IRRIGATION ON AND OFF. The growers acquire weather information from similar sources (e.g., on-farm weather stations and FAWN or GAEMN), and they also have similar responses toward the importance of following temperature, dew point, and bud stage as criteria for frost protection decision management. However, the survey identifies that growers have differing opinions on when they make the decision to frost protect.

In total, when asked to select only one, $28 \%$ of respondents reported using dry bulb air temperature compared with $72 \%$ using wet bulb temperature to determine when to use frost protection, with significantly more growers in Florida using the dry bulb

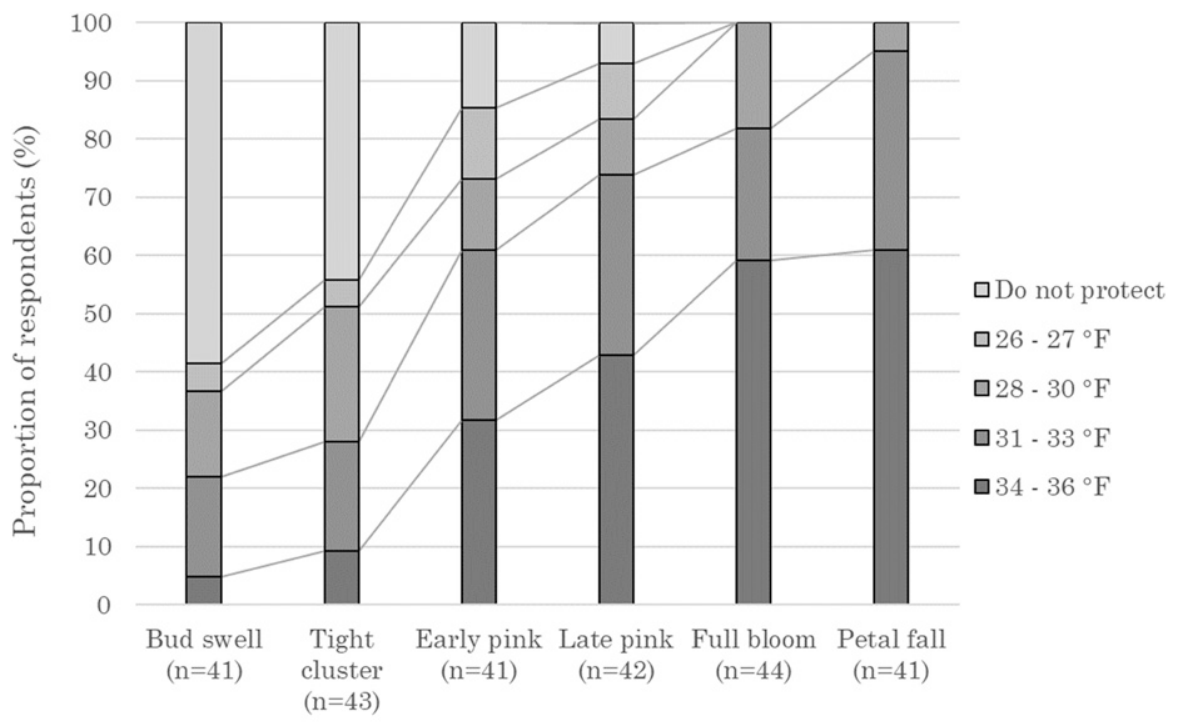

Bud Stages

Fig. 2. Proportion of surveyed Florida and Georgia blueberry growers who reported initiating irrigation for frost protection at size different floral bud stages, by temperature range. Responses to the question, "For the following bud stages, for nights where the temperature is predicted to drop below freezing $\left(32{ }^{\circ} \mathrm{F}\right)$, please select the air temperature $\left({ }^{\circ} \mathrm{F}\right)$ at which you turn on your irrigation system for frost protection" (only respondents indicated using wet bulb temperature to determine when to use frost protection $) ;\left({ }^{\circ} \mathrm{F}-32\right) \div 1.8={ }^{\circ} \mathrm{C}$. temperature in irrigation initiation $[38.5 \%$, compared with $18.6 \%$ in Georgia $\left(\chi^{2}\right.$ test, $\left.\left.P=0.05\right)\right]$.

Examining only the subset of respondents who indicated using wet bulb temperature in determining when to frost-protect crops, we found that the decision when to turn the system on and off varied (Fig. 2). The decision to turn the system on and off was grower-dependent regardless of input information and was influenced by region. The difference among growers is especially noticeable for tight cluster and early pink floral stages, when some growers turn their systems on when temperatures reach 34 to $36^{\circ} \mathrm{F}$, whereas others do not protect. For these two bud stages, responses of Florida and Georgia growers differed greatly. For the tight cluster stage, the majority of Georgia respondents selected "do not protect" $(66.7 \%)$, whereas only $22.7 \%$ of respondents from Florida selected the same answer $\left(\chi^{2}\right.$ test, $\left.P=0.05\right)$. Similarly, for the early pink stage, $25 \%$ of the Georgia responses were "do not protect" compared with $4.8 \%$ of such responses in Florida. The willingness of some growers to protect at any stage could be due to an information deficit, where growers are unfamiliar with critical bud temperatures. However, given that $85.1 \%$ of respondents ranked bud stage as "very important" in the decision to activate irrigation, it could alternatively reflect grower preference for caution in protecting their investment, especially in Florida with higher early season prices.

There is also a range of temperatures used by growers to turn the system off (Fig. 3), which affects the duration of frost-protection irrigation. The decision of when to turn the frost protection on/off can significantly affect water use and potential cost savings to the growers.

Moreover, when asked how many times they had turned on irrigation due to cold temperatures in the past season, the number of events for which growers reported initiating frost protection differed among respondents. From Fall 2014 through Spring 2015, growers activated irrigation an average of 5.2 times (the median was 4 ), with a range from 0 to 20 times during the season. Georgia respondents reported engaging irrigation systems 5.4 times on average (the median was five), whereas for the 
Florida respondents the average was 5.0 times (the median was three) (Fig. 4). State-based differences in the number of events for which growers initiated irrigation for frost protection were statistically inconclusive. Although analysis of variance and median scores tests failed to reject the hypothesis that the responses from Georgia and Florida were drawn from a distribution with the same

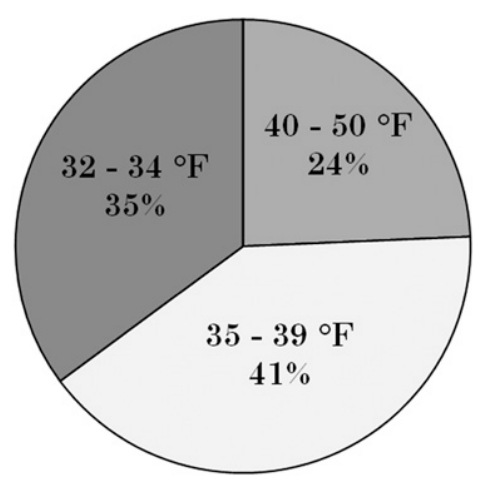

Fig. 3. Proportion of Florida and Georgia blueberry growers who reported turning off their irrigation systems at different temperature ranges after using irrigation as an active frost-protection measure. Responses to the question, "What air temperature $\left({ }^{\circ} \mathbf{F}\right)$ do you consider to be critical for turning off your irrigation system?" [only includes respondents who reported using wet bulb temperature to determine when to use frost protection $(n=37)] ;\left({ }^{\circ} \mathbf{F}-\right.$ $32) \div 1.8={ }^{\circ} \mathrm{C}$.

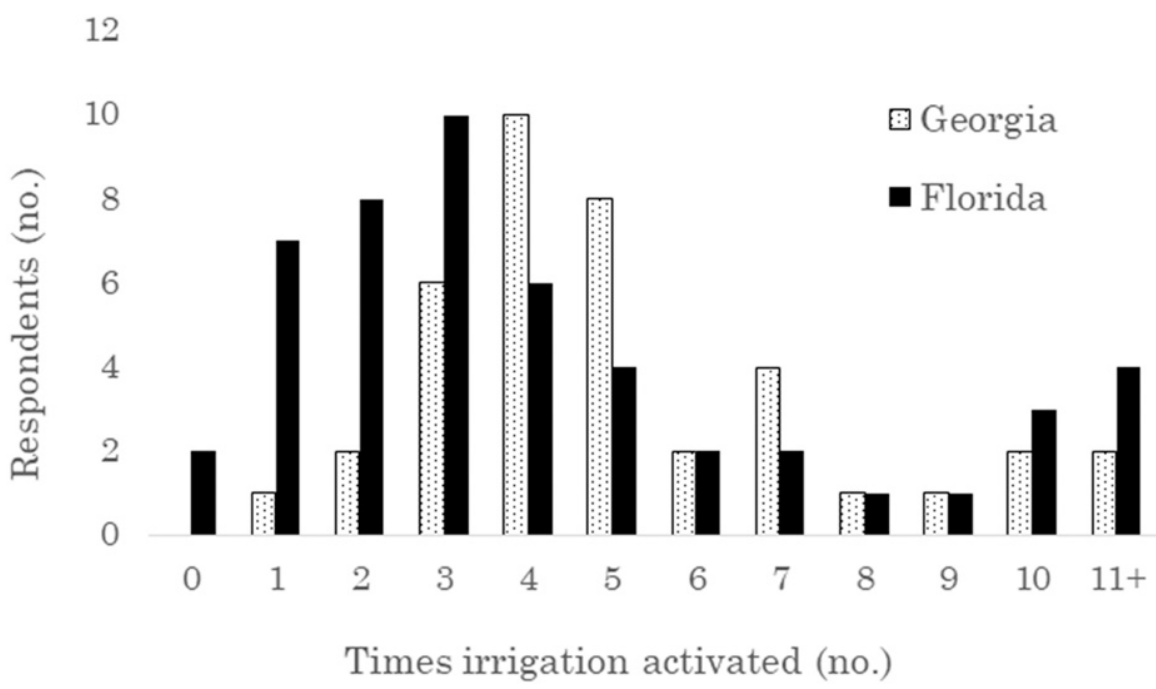

Fig. 4. The number of times blueberry growers in Georgia and Florida reported activating irrigation for frost protection during the Fall 2014 to Spring 2015 season $(n=89)$. Response data are from a survey of frost-protection practices and decision criteria by blueberry growers in Florida and Georgia administered at extension meetings in 2015 and 2016. mean and median $(P=0.1)$, the twosided Wilcoxon rank-sum test $(P=0.1)$ and the asymptotic KolmogorovSmirnov two-sample test $(P=0.5)$ rejected the hypothesis that the responses were from the same distribution. We further identified five smaller general regions with similar climatological conditions in the two states based on information from AgroClimate (2018) and even within these smaller regions, the range of the responses regarding the number of frost-protection irrigation events was large (Table 8).

The differences in the frostprotection practices may be attributed to growers' perceptions concerning frost-protection risks and the impact of risk on yields (Fig. 5). Approximately $25 \%$ of respondents said that they could lose $20 \%$ to $29 \%$ of floral buds and $\approx 40 \%$ said they could lose $30 \%$ to $49 \%$ of buds and still have sufficient yield to produce a marketable crop.

WATER USE AND COST OF OPERATION FOR IRRIGATED FROST PROTECTION. Of the respondents who use irrigation for frost protection, approximately $69 \%$ operate diesel pumping systems, $18 \%$ operate electric pump systems, and $13 \%$ operate both diesel and electric pumping systems on their farms (Table 9). Many variable inputs are involved in identifying the cost of operation for an irrigated frost-protection system. Inputs include sprinkler rating

(inches per hour), number of sprinklers, pump efficiency rating, gallons of diesel consumed to deliver an acreinch of water, and the price of a gallon of water. Pump efficiency and gallons consumed per acre-inch of water information can be found in Martin et al. (2011), and sprinkler rating can be calculated from information in Tyson et al. (2006). As an example, sprinkler nozzles are rated for 0.15 inch $/ \mathrm{h}$, and the pump demand is $67.9 \mathrm{gal} / \mathrm{min}$ per acre in a $60 \times$ 60 - $\mathrm{ft}$ irrigation pattern. To calculate the water used by a sprinkler head, the following relationship can be used:

$$
\begin{aligned}
& (67.9 \mathrm{gal} / \mathrm{min} \mathrm{A})(60 \mathrm{~min} / 1 \mathrm{~h}) \\
& (\mathrm{A} \text { inch } / 27,154 \mathrm{gal})=0.15 \mathrm{inch} / \mathrm{h}
\end{aligned}
$$

In a $60 \times 60$-ft pattern of sprinklers, there are 12.1 sprinklers in an acre $\left(3600 \mathrm{ft}^{2} \div 43,260 \mathrm{ft}^{2}=12.1\right)$. In a system pumping at 45 psi with $0 \mathrm{ft}$ of lift, 0.95 gal of diesel will be consumed per acre-inch of water applied. Pump efficiency is considered at $90 \%$ efficiency and 1.11 is used as the multiplier, and fuel cost is $\$ 2.50$ per gallon of diesel (price as of June 2017) (U.S. Department of Energy, 2018). Given these assumptions, the irrigation costs are:

$$
\begin{gathered}
(0.25 \mathrm{inch} / \mathrm{h})(12.1)(1.1 \mathrm{l})(0.95 \mathrm{gal}) \\
(\$ 2.50 / \mathrm{gal})=\$ 7.97 \mathrm{inch} / \mathrm{h}
\end{gathered}
$$

To identify the operational cost using electricity, convert diesel to electricity by using a conversion factor of $14.12 \mathrm{gal} / \mathrm{kWh}(1.00$ diesel factor $\times 14.12$ electrical factor $=$ 14.12):

$$
\begin{aligned}
& (0.25 \mathrm{inch} / \mathrm{h})(12.1)(1.11)(0.95 / \mathrm{gal}) \\
& \times(14.12 \mathrm{gal} / \mathrm{kWh})(\$ 0.10 \mathrm{kWh}) \\
& =\$ 4.50 \mathrm{inch} / \mathrm{h}
\end{aligned}
$$

If frost protecting 10 acres for $6 \mathrm{~h}$, the cost of frost protection equals $\$ 478.20$ or $\$ 270.00$ for diesel or electric systems, respectively. Although growers are divided on the importance of freeze duration and the majority responded that marketable yield could be $51 \%$ to $70 \%$ bud survival, this suggests growers may delay frost protection to conserve water resources or expenses.

Given that the average number of frost events reported by the growers in both states was about five 
Table 8. The self-reported number of times irrigation was activated for frost protection grouped by geographic regions in Florida (FL) and Georgia (GA). ${ }^{\mathrm{z}}$

\begin{tabular}{|c|c|c|c|c|c|c|}
\hline \multirow[b]{2}{*}{ Region } & \multirow[b]{2}{*}{ Counties } & \multirow[b]{2}{*}{ Responses (no.) } & \multicolumn{4}{|c|}{ Times irrigation activated (no.) } \\
\hline & & & Mean & Median & Minimum & Maximum \\
\hline I & $\begin{array}{l}\text { Appling, Atkinson, Bacon (GA); Baker (FL); Brantley, } \\
\text { Burke, Coffee, Jeff Davis, Pierce, Wilcox (GA) }\end{array}$ & 33 & 4.4 & 4.0 & 1 & 10 \\
\hline II & $\begin{array}{l}\text { Camden, Charlton, Clinch, Glynn, Lanier (GA); } \\
\text { Leon (FL); Ware/Clinch (GA) }\end{array}$ & 16 & 6.9 & 6 & 3 & 18 \\
\hline III & Alachua, Marion, Putnam, Suwannee (FL) & 9 & 9.0 & 6 & 0 & 20 \\
\hline
\end{tabular}

${ }^{\mathrm{z}}$ The responses are from a survey of frost protection practices by blueberry growers in FL and GA. The table combines responses to the questions "what is the county of your operation" and "how many times did you turn your irrigation on due to cold temperatures during the past season (Fall 2014 to Spring 2015 )?"

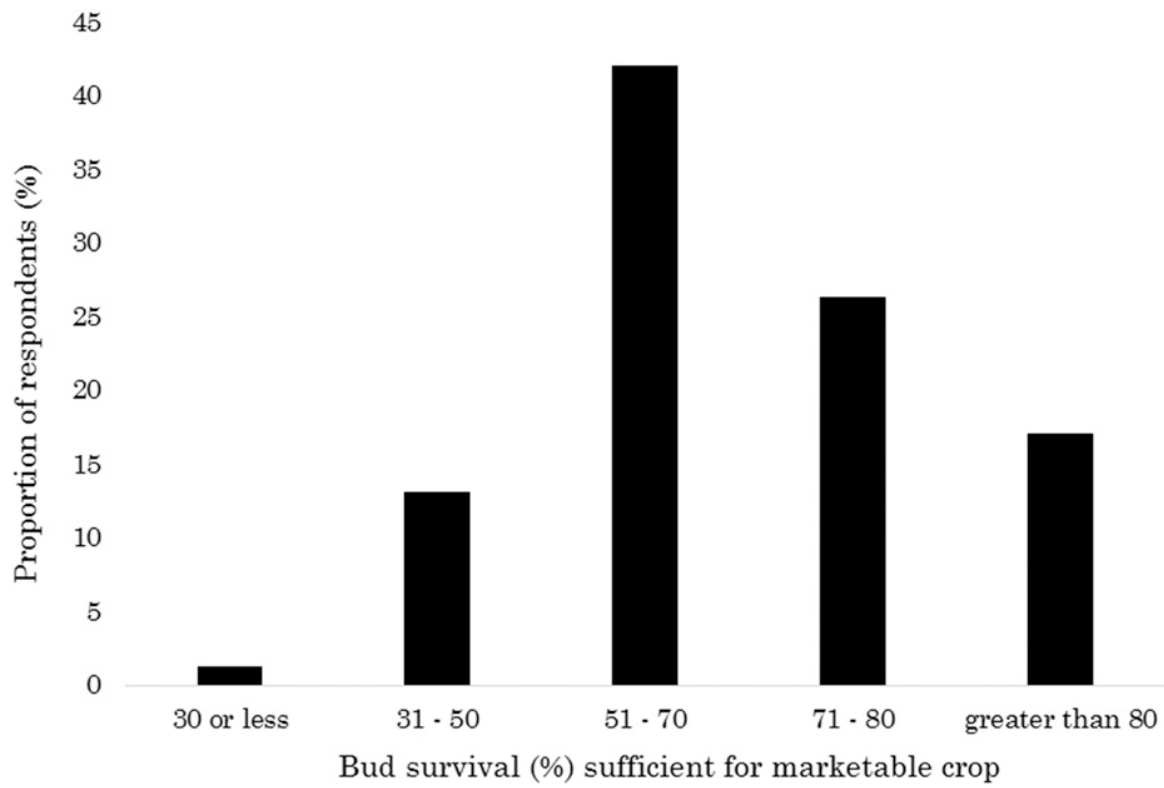

Fig. 5. Distribution of responses by Florida and Georgia blueberry growers to the question, "What minimum percentage of bud survival per bush is sufficient to produce a marketable crop?" $(n=81)$. From a survey of freeze-protection practices and decision criteria by blueberry growers in Florida and Georgia administered at extension meetings in 2015 and 2016.

Table 9. Types of irrigation pumps used by Florida and Georgia blueberry growers. $^{\mathrm{z}}$

\begin{tabular}{lcccc}
\hline & & \multicolumn{3}{c}{ Proportion of respondents (\%) } \\
\cline { 3 - 5 } State & Respondents (no.) & Diesel & Electric & Both \\
\hline Florida & 44 & 79.6 & 6.8 & 13.6 \\
Georgia & 49 & 59.2 & 28.6 & 12.2 \\
Total sample & 93 & 68.8 & 18.3 & 12.9 \\
\hline
\end{tabular}

${ }^{\mathrm{z}}$ Response data are from a survey of blueberry grower freeze protection practices and decision criteria answering the question "what type of pump motor is most frequently used?" The proportion of pump motors used between the states was statistically significant (Pearson's $\chi^{2}$ test, $P=0.02$ ).

(for 2014-15), delaying switching the system on by an hour for each event means a reduction in irrigation by $5 \mathrm{~h}$ in the entire season. If sprinkler nozzles are rated for $0.15 \mathrm{inch} / \mathrm{h}$, the pump demand is $67.9 \mathrm{gal} / \mathrm{min}$ per acre in a $60 \times 60$ - $\mathrm{ft}$ irrigation pattern, or $4074 \mathrm{gal} / \mathrm{h}$ per acre, which for an irrigation run time of $5 \mathrm{~h}$ accounts for $20,370 \mathrm{gal} /$ acre. Blueberry acreage varied among respondents, from less than five acres to more than 75 acres. For a grower with five acres of blueberry, a 5 -h reduction in irrigation could translate into 101,850 gal of water-use reduction, whereas for a farmer with 75 acres, this would translate into $1,527,750$ gal. For comparison, domestic per-capita water-use rate is $87 \mathrm{gal} / \mathrm{d}$ (Marella, 2014), meaning that a family of three people would use 31,777 gal over 1 year. Therefore, even a 5 -h reduction in frost-protection irrigation can result in a significant water use savings. Such water-use reduction can be important in the areas like Florida, where traditional water supply sources are not able to sustain increasing water demand driven by the growing population (Economic and Demographic Research, 2018).

\section{Conclusions}

To meet consumer demands for blueberry, production in Florida and Georgia increased from 2000 to $2015 \times$ $293 \%$ and $274 \%$, respectively. Even though the price per pound decreased for Florida and Georgia by $34 \%$ and $15 \%$, respectively (USDA, 2013, 2017), prices remain relatively high, making growers especially concerned about the risk of losing crops due to freeze. Our survey showed that Florida and Georgia growers frost-protect 'Farthing' and 'Emerald' (Lyrene, 2008; Williamson et al., 2014), which are early flowering varieties in both regions, susceptible to spring frosts. Further, growers are willing to frostprotect crops for the duration of the event and are not overly concerned about the length of time. The majority of growers are willing to wait until the temperature is above the $35{ }^{\circ} \mathrm{F}$ wet-bulb temperature before turning the irrigation system off, regardless of operational cost.

A descriptive study of fruit growers in Yakima Valley, WA, found that growers exchanged information when monitoring frost events (Stewart et al., 
1984). Similarly, in our survey, growers were more inclined to consult with other growers for information over other resources. As Stewart et al. (1984) noted, growers tend to communicate with one another during the vigilant period of a freeze despite business competition.

As a result of the risks of freezerelated crop damage and the benefits and drawbacks of irrigation for frost protection, precision is important. The blueberry frost survey provides additional information about frost-protection use, decision criteria related to initiation and termination, sources of information used, and types of irrigation systems. This information can be used by extension to design a strategy to more efficiently disseminate frost warnings and irrigation advice to growers. The survey results also provide a baseline of irrigation frostprotection habits against which to compare future intervention, such as the dissemination of more precise irrigation recommendations.

\section{Literature cited}

AgroClimate. 2018. Freeze risk probabilities: Last freeze forecast. AgroClimate: Tools for managing climate risk in agriculture. 11 Mar. 2018. <http:// agroclimate.org/tools/freeze-riskprobabilities $/>$.

Brazelton, C. 2015. 2014 World blueberry statistics \& global market analysis. U.S. Highbush Blueberry Council, Folsom, CA.

Chevalier, R.F., G. Hoogenboom, R.W. McClendon, and J.O. Paz. 2012. A webbased fuzzy expert system for frost warnings in horticultural crops. Environ. Model. Softw. 35:84-91.

Crane, T., C. Roncoli, J.O. Paz, N. Breuer, K. Broad, K. Ingram, and G. Hoogenboom. 2010. Forecast skill and farmers' skills: Seasonal climate forecasts and agricultural risk management in the southeastern United States. Weather Clim. Soc. 2:44-59.

Economic and Demographic Research. 2018. Annual assessment of Florida's water resources and conservation lands: 2018 edition. 11 Mar. 2018. <http://www.edr. state.fl.us/Content/natural-resources/ LandandWaterAnnualAssessment 2018Edition.pdfs.

England, G. 2015. An overview of the blueberry industry in Florida. J. Amer. Pomol. Soc. 69:2-3.

Fonsah, E.G., J. Massonnat, L. Wiggins, G. Krewer, D. Stanaland, and J.E. Smith.
2013. Southern highbush blueberry marketing and economics. Univ. Georgia Ext. Bul. 1413.

Hu, Q., L.M. Pytlik Zillig, G. Lynne, A. Tomkins, W. Waltman, M. Hayes, K. Hubbard, I. Artikov, S. Hoffman, and D. Wilhite. 2006. Understanding farmers' forecast use from their beliefs, values, social norms, and perceived obstacles. J. Appl. Meteorol. Climatol. 45:1190-1201.

Klockow, K.E., R.A. McPherson, and D.S. Sutter. 2010. On the economic nature of crop production decisions using the Oklahoma Mesonet. Weather Clim. Soc. 2:224-236.

Kusunose, Y. and R. Mahmood. 2016. Imperfect forecasts and decision making in agriculture. Agric. Syst. 146:103-110.

Lyrene, P.M. 2008. 'Emerald' southern highbush blueberry. HortScience 43:16061607.

Marella, R.L. 2014. Water withdrawals, use, and trends in Florida, 2010. U.S Geological Survey USGS Rpt. 20145088. 11 Mar. 2018. <https://pubs.er. usgs.gov/publication/sir20145088>.

Martin, D.L., T.W. Dorn, S.R. Melvin, A. J. Corr, and W.L. Kranz. 2011. Evaluating energy use for pumping irrigation water. Proc. 23rd Annu. Central Plains Irr. Conf., Burlington, $\mathrm{CO}, 22-23$ Feb. 2011. p. 104-116.

Mase, A.S. and L.S. Prokopy. 2014. Unrealized potential: A review of perceptions and use of weather and climate information in agricultural decision making. Weather Clim. Soc. 6:47-61.

Michigan State University. 2012. Critical spring temperatures. 11 Mar. 2018. <http:// www.canr.msu.edu/blueberries/weather/ critical-spring-temperatures>

NeSmith, D.S. 2008. 'Rebel' southern highbush blueberry. HortScience 43:15921593.

Patten, K., E. Neuendorff, G. Nimr, J.R. Clark, and G. Fernandez. 1991. Cold injury of southern blueberries as a function of germplasm and season of flower bud development. HortScience 26:18-20.

Perry, K.B. 1998. Basics of frost and freeze protection for horticultural crops. HortTechnology 8:10-15.

Poling, E.B. 2008. Spring cold injury to wine grapes and protection strategies and methods. HortScience 43:1652-1662.

Singerman, A., M. Burani-Arouca, J.G. Williamson, and G.K. England. 2016. Establishment and production costs for southern highbush blueberry orchards in Florida: Enterprise budget and profitability analysis. Univ. Florida, Inst. Food Agr. Sci. Ext. Bul. FE1002.

Simnitt, S., T. Borisova, D. Chavez, and M. Olmstead. 2017. Frost protection for Georgia peach varieties: Current practices and information needs. HortTechnology 27:344-353.

Snyder, R.L. and J.P. Melo-Abreu. 2005. Frost protection: Fundamentals, practice and economics. Vol. 1. Food Agr. Organization United Nations, Rome, Italy.

Spiers, J.M. 1978. Effect of stage of bud development on cold injury in rabbiteye blueberry. J. Amer. Soc. Hort. Sci. 103:452455 .

Stewart, T.R., R.W. Katz, and A.H. Murphy. 1984. Value of weather information: A descriptive study of the fruitfrost problem. Bull. Amer. Meteorol. Soc. 65:126-137.

Strik, B.C. and D. Yarborough. 2005. Blueberry production trends in North America, 1992 to 2003, and predictions for growth. HortTechnology 15:391-398.

Tyson, A.W., R.E. Sneed, C.M. Mainland, K.B. Perry, E.B. Poling, and D.C. Sanders. 2006. Frost/freeze protection by sprinkler irrigation. 28 Dec. 2017. <http://www. smallfruits.org/assets/documents/ weather/SRSFC-Weather.pdfs.

U.S. Department of Agriculture. 2013. Noncitrus fruits and nuts summary, various issues. 4 Apr. 2018. <https://usda. mannlib.cornell.edu/MannUsda/ vi e w D o c u m e n t I fo.do? documentID $=1765=1765>$.

U.S. Department of Agriculture. 2017. Noncitrus fruits and nuts: 2016 Summary. 4 Apr. 2018. <https://usda. mannlib.cornell.edu/usda/nass / NoncFruiNu//2010s/2017/ NoncFruiNu-06-27-2017.pdf $>$.

U.S. Department of Energy. 2018. Weekly U.S. no. 2 diesel retail prices. 11 Mar. 2018. <https://www.eia.gov/ dnav/pet/pet_pri_gnd_dcus_nus_w. htm>.

Warmund, M.R, P. Guinan, and G. Fernandez. 2008. Temperatures and cold damage to small fruit crops across the eastern United States associated with the April 2007 freeze. HortScience 43:1643-1647.

Warner, L.A., A. Harder, T. Wichman, and F. Dowdle. 2014. Increasing efficiency in extension using the train-thetrainer approach. Univ. Florida, Inst. Food Agr. Sci. Ext. Bul. AEC517.

Williamson, J.G., J.W. Olmstead, G.K. England, and P.M. Lyrene. 2014. Southern highbush cultivars from the University of Florida. Univ. Florida, Inst. Food Agr. Sci. Ext. Bul. HS1245. 